\title{
Characteristic Physico-chemical Properties and Potential Uses of Enset (Ensete ventricosum) Starch: Comparative Studies with Starches of Potato, Sago and Corn
}

\author{
(Received October 14, 2009; Accepted March 3, 2010)
}

\author{
Rieko Hirose, ${ }^{1}$ Yoriko Tezuka, ${ }^{2}$ Tomoko Kondo, ${ }^{2}$ Kazuko Hirao, ${ }^{3}$ Tamao Hatta, ${ }^{4}$ Seiko Nemoto, ${ }^{4}$ \\ Kyoko Saio, ${ }^{3}$ Setsuko Takahashi ${ }^{2}$ and Keiji Kainuma ${ }^{4, *}$ \\ ${ }^{1}$ Tokyo Metropolitan Food Technology Research Center (1-9, Kandasakuma-cho, Chiyoda-ku, Tokyo 101-0025, Japan) \\ ${ }^{2}$ Kyoritsu Women's University (2-2-1, Hitotsubashi, Chiyoda-ku, Tokyo 101-8437, Japan) \\ ${ }^{3}$ Aikoku Gakuen Junior College (5-7-1, Nishikoiwa, Edogawa-ku, Tokyo 133-8585, Japan) \\ ${ }^{4}$ Japan International Research Center for Agricultural Sciences (1-1, Ohwashi, Tsukuba 305-8686, Japan)
}

\begin{abstract}
Enset (Ensete ventricosum, Family Musaceae) is a plant distributed in Eastern and Southern Africa, often called "false banana" for its close resemblance to the banana plant (Musa acuminate, Family Musaceae). The plant is only cultivated in Southern and Southwestern Ethiopia as a staple. Enset accumulates starch in the pseudostem and underground corm. Though enset starch is utilized in foods and for industrial purposes such as textile and paper sizing, pharmaceuticals, very limited research has been done on the properties of the extracted starch. The useful properties of enset starch were characterized by comparison with starches of potato, sago and corn and shown in a starch diagram, where the analytical results including granule size, $\mathrm{X}$-ray diffraction pattern, amylose content, gelatinization behavior, stability and various rheological properties of gel are presented in comparison with those of reference starches. The characteristics of gelatinization behaviors, quick gel formation, gel stability during cold storage, and high firmness and stickiness of enset starch gel described in this paper would be useful for various foods, for example, in Blanc-mange and Japanese sweet "Kudzu mochi" for body formation, and in various sauces and soups as a thickener due to stable starch viscosity and high gel stickiness during storage. The gel whiteness of enset starch is appropriate for milk or soybean curd containing processed foods, where pure white color is appreciated. Properties of enset starch gel will be widely useful as a body forming agent and thickener of various foods in home cooking and food industries.
\end{abstract}

Key words: enset starch, photopastegraphy, physico-chemical property, starch diagram

Enset (E. ventricosum, Family Musaceae) is an important traditional Ethiopian staple crop widely distributed in Eastern and Southern Africa but only cultivated in Southern and Southwestern Ethiopia to feed about 15 million people by mixed subsistence farming system. ${ }^{1)}$ Though the taxonomy and distribution of enset species need further research, current data revealed two wild enset species distributed over much of Asia and four wild species in subSaharan Africa and Madagascar. E. ventricosum, the only known wild species in Ethiopia, is concentrated in the southern highlands. ${ }^{2)}$ It is often called "false banana" for its morphologically close resemblance to the domesticated banana plant (M. acuminate, Family Musaceae). ${ }^{3)}$

Being different from banana, enset accumulates starch mainly in the pseudostem and underground corms, which is utilized as a starch resource for foods and industrial purposes. It takes four to five years for maturation, at which time a single corm will give $40 \mathrm{~kg}$ of food. The starch extraction process is somewhat similar to that of sago palm (Metroxylon sagu), which accumulates starch in stems and is mainly grown in Southeast Asia. After removing the cellular materials, pseudostem sheath extracts

${ }^{*}$ Corresponding author (Tel. +81-29-851-6545, Fax. +81-29-8588340, E-mail: keijikai@aol.com). are packed in enset leaves and fermented in the soil to obtain "Cocho", which is similar to a pancake like bread. Underground corm is also packed in enset leaves and steamed or boiled to prepare a traditional staple food. ${ }^{2}$

Though enset starch is utilized in the foods mentioned above and for industrial purposes such as textile and paper sizing and pharmaceuticals, very limited research has been done on the properties of the extracted starch. ${ }^{3)}$ We tried to characterize the useful properties of enset starch by comparing it with commercially produced starches of potato, sago and corn. Sago starch was specifically selected for comparison in this study since sago grows in a similar tropical environment and the starch is similarly extracted from the stem of the sago palm tree.

The results shown in this paper will hopefully be useful for further utilization of enset starch for food and industrial purposes.

\section{MATERIALS AND METHODS}

Materials. An enset plant, estimated to be seven to ten years old, is shown in Fig. 1. For microscopic observation, four- to five-year-old tissue was used from a plant that was donated by a farm belonging to the Awelatulla Agriculture Office of Southern Nations, Nationalities, and 


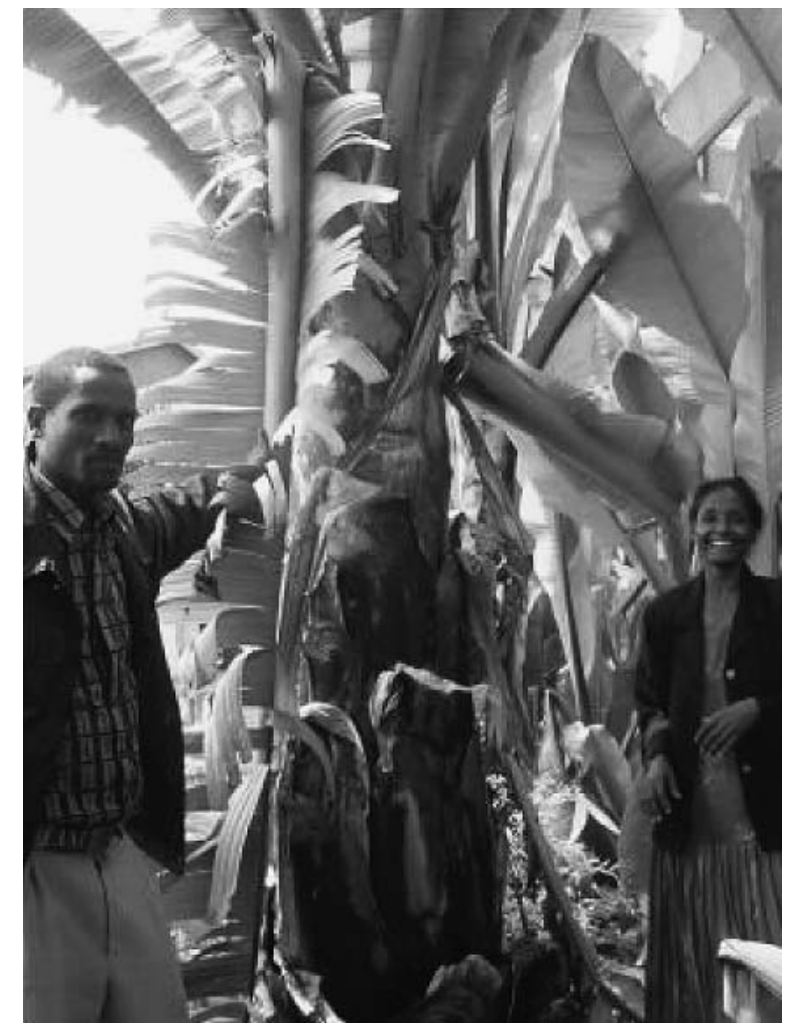

Fig. 1. Photo of enset plant estimated to be 7 to 10 years old.

Plant is cultivated in the field of the Awelatulla Agriculture Office of Southern Nations, Nationalities and People's Republic in Ethiopia.

People's Republic in Ethiopia. Commercial food grade enset starch was donated by Mr. Yitbarek Alemu, General Manager of Starch, Chemicals and Adhesives Industry to one of the authors, K. Saio, and Mr. Mado of Sasakawa African Association in Addis Ababa.

\section{Methods.}

Starch preparation. The enset starch was further refined by rinsing five times in distilled water and then dried at room temperature. The refined starch was sieved with 200 mesh to remove foreign material. For the comparison of starch properties, commercial starches of potato (Hokuren Nakashari Factory, Hokkaido, Japan), Sago (Sarawak, Malaysia donated by Shimada Kagaku Kogyo Co., Ltd., Nagaoka, Japan) and corn (Nihon Shokuhinkako Co., Ltd., Shizuoka, Japan) were purified by the same method as enset starch.

Microscopic observation. Optical microscopic observation was carried out by differential interference contrast microscopy with a Nikon Optiphoto-2 (Nikon Corporation, Tokyo, Japan). The sample was prepared by suspending starch granules in water, placing them on a slide sheet with water and observing them with transmission light after drying. A Hitachi Tabletop TM-1000 Scanning Electron Micrograph (Hitachi High-Technology Corporation, Tokyo, Japan) was used for the observation of the cross section of leaf sheath, tissue of corm of enset and starch granule without coating at $15 \mathrm{kV}$ accelerated electron.

Proximate composition analysis. The proximate composition of starch samples was analyzed as follows: Mois- ture content was determined by heating the starch at $135^{\circ} \mathrm{C}$ for $1 \mathrm{~h}^{4}{ }^{4)}$ Nitrogen content was determined by the Kjeldahl Method and multiplied by 6.25 to obtain protein content. ${ }^{5)}$ Fat content was determined by extraction with a mixed solvent of water containing chloroform and methanol. ${ }^{6)}$ Ash content was determined by heating at $550^{\circ} \mathrm{C} .^{7)}$

Granule size distribution. Starch samples were dispersed with an ultrasonic bath and counted to 30,000 granules by Coulter-Multisizer II, Isotone II (Beckman Coulter Inc., Brea, USA). Average granule sizes were calculated using the following equation:

Average granule size $D(p, q)=\left[\sum_{n i x i}{ }^{p} / \Sigma n i x i^{q}\right]^{(1 / p-q)}$, where $x$ is the median of the histogram, $n i$ is percentage of granules in histogram number $i$., and $p$ and $q$ are constant numbers where $p$ is not equal to $q(p \neq q)$.

Viscosity measurement. Viscosity change during heating in water was continuously measured by Rapid Visco Analyzer (RVA-3D, Newport Scientific Pty. Ltd., Warriewood, Australia). The measuring condition was used as described in Deffenbaugh and Walker. ${ }^{8}$ A $7.5 \%$ (w/w) starch suspension was kept at $50^{\circ} \mathrm{C}$ for $1 \mathrm{~min}$, and then the temperature was increased at the rate of $5.6^{\circ} \mathrm{C} / \mathrm{min}$ until reaching $95^{\circ} \mathrm{C}$. After being kept at $95^{\circ} \mathrm{C}$ for $2 \mathrm{~min}$, the temperature was then dropped at the rate of $5.6^{\circ} \mathrm{C}$ / min until reaching $50^{\circ} \mathrm{C}$. Gelatinization temperature, maximum viscosity, minimum viscosity, and viscosity at $50^{\circ} \mathrm{C}$ of starches were measured by the viscograms.

$X$-ray diffraction pattern. X-ray powder diffraction patterns of starches were determined by Rad-X (Rigaku Corporation, Tokyo, Japan) under the following conditions: voltage at $40 \mathrm{kV}$, current at $25 \mathrm{~mA}$, scan step at $0.02^{\circ}$, scan speed at $2^{\circ} / \mathrm{min}$ and slits at $1^{\circ}$ (DS) $-0.3 \mathrm{~mm}(\mathrm{RS})-1^{\circ}$ (SS).

Amylose content. Amperometric titration for amylose determination was done as by $\mathrm{Baba}^{9)}$ using an automatic amperometric titrator of ART-3 (Hirama Laboratories Co., Ltd., Kawasaki, Japan). After defatting by $85 \%$ methanol, starch was titrated with $0.523 \mathrm{mM} \mathrm{KIO}_{3}$ solution, which was equivalent to the $0.00157 \mathrm{~N} \mathrm{KIO}_{3}$ solution described in a reference. ${ }^{9}$ Amylose content was calculated as follows: Amylose content $(\%)=$ Iodine binding of sample starch/Iodine binding of amylose $\times 100$, where 18 was used for Iodine binding of pure amylose.

Photopastegraphy. Photopastegraphy was carried out as by Kainuma ${ }^{10,11)}$ using a ART-3PP-1 Photopastegraph (Hirama Laboratories Co., Ltd.). A starch suspension $(0.3 \%, w / w)$ was stirred for 2 min at $25^{\circ} \mathrm{C}$ in a $50 \mathrm{~mL}$ cell; then the temperature was increased at the rate of $2^{\circ} \mathrm{C} / \mathrm{min}$. The change in light transmittance of the starch suspension at $372 \mathrm{~nm}$ was determined from $25^{\circ} \mathrm{C}$ to $95^{\circ} \mathrm{C}$.

Whiteness of starch gel. The change in whiteness of the starch gel prepared by a Rapid Visco Analyzer was determined by a Handy Spectrophotometer NF333 (Nihon Denshoku Industries Co., Ltd., Tokyo, Japan). Starch gel filled a glass cell and was kept at room temperature for 0 , 5, 10, 15, 30 and $45 \mathrm{~min}$, and 1, 2, 3, 4 and $24 \mathrm{~h}$, and then Hunter whiteness was determined. Whiteness of the powder before gelatinization was determined by filling the cell with a powder sample.

Starch gel properties. Gel texture was determined by the two-bite determination method using a uniaxial com- 
pression rheometer (Tensipresser TTP-50-BX, Taketomo Electric Inc., Tokyo, Japan). The starch gel prepared by a Rapid Visco Analyzer was poured into a Tensipresser cell $(\phi 24 \mathrm{~mm} \times$ depth $6 \mathrm{~mm}$ ), the perimeter of which was wrapped with drafting tape in order to permit a gel height approximately $6 \mathrm{~mm}$ over the rim of the cell, and covered with flexible film (PARAFILM M, Pechiney Plastic Packaging Co., Chicago, USA). After the starch gel was kept for $30 \mathrm{~min}$ at $25^{\circ} \mathrm{C}$, the gel was transferred to a refrigerator at $5^{\circ} \mathrm{C}$ and kept for 2 and $24 \mathrm{~h}$. Immediately before the determination, the drafting tape was removed, and then the excess gel above the rim was cut by piano wire in order to obtain a freshly cut smooth surface of the test piece. The texture of the gel was determined using a cylindrical plunger $(\phi 11.25 \mathrm{~mm})$ which compressed the test piece until $90 \%$ deformation at $2 \mathrm{~mm} / \mathrm{s}$. Firmness, adhesiveness, cohesiveness and stickiness were calculated from the data obtained by the two-bite determination method using the Texture Profile Analysis ${ }^{12)}$ Program installed in the Tensipresser.

\section{RESULTS}

\section{Structural characteristics of leaf sheath and corm of enset.}

An enset plant with farmers is shown in Fig. 1. In this photo, the plant has almost reached harvest time with a large pseudostem and probably corm under ground. There are several winding leaves that rise straight, unlike on banana trees. A cross section of leaf sheath was prepared and observed under scanning electron microscopy (SEM). Figure 2 (A) shows a sketch of a cross section of a leaf sheath, which is divided by thin sheet-like walls stained with Fass reagent or Lugol's solution and there are milky

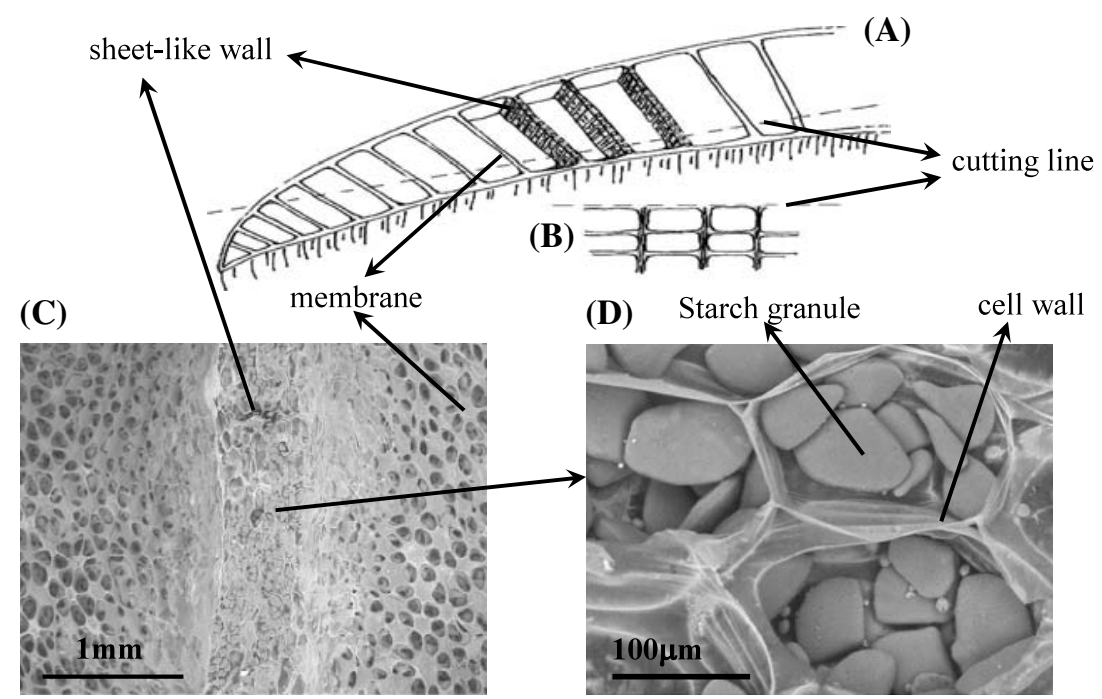

Fig. 2. Scanning electron micrographs of enset leaf sheath.

(A) and (B) Sketches of a cross section of leaf sheath observed at the cutting line. (C) and (D) SEM images of the internal organs of the leaf sheath.

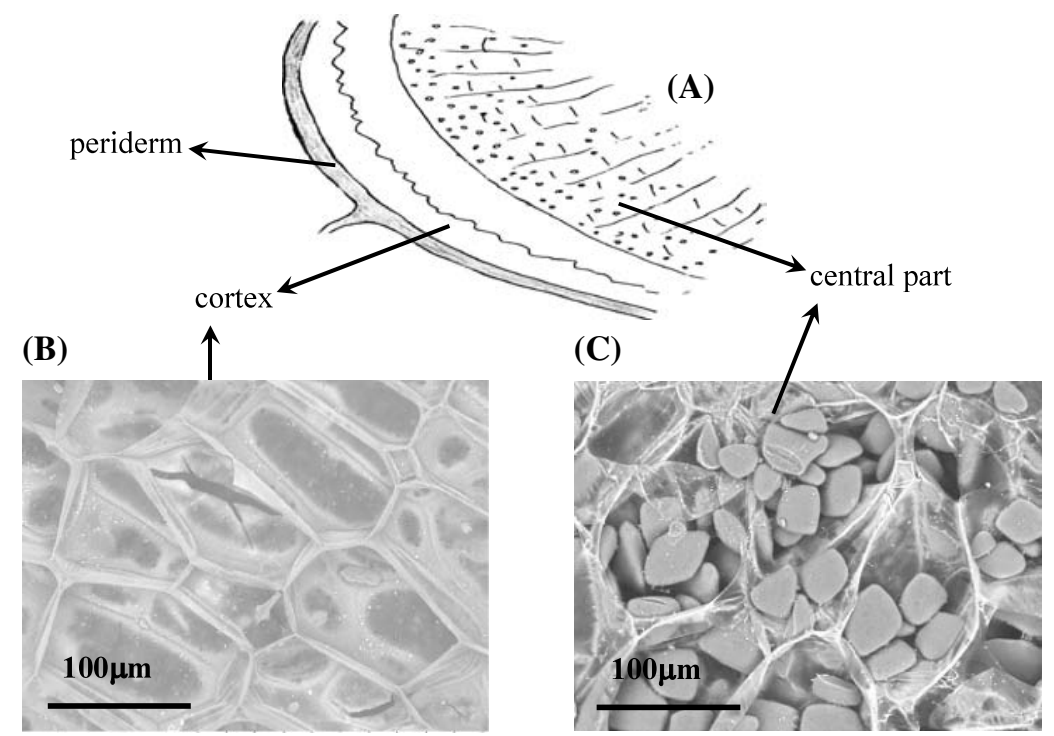

Fig. 3. Scanning electron micrographs of enset corm.

(A) Sketch of a cross section of enset corm where the outer layers of the periderm and cortex consist mainly of soft cells. Starch granules are observed only in the central part. (B) and (C) SEM images of the cortex and central part, respectively. 


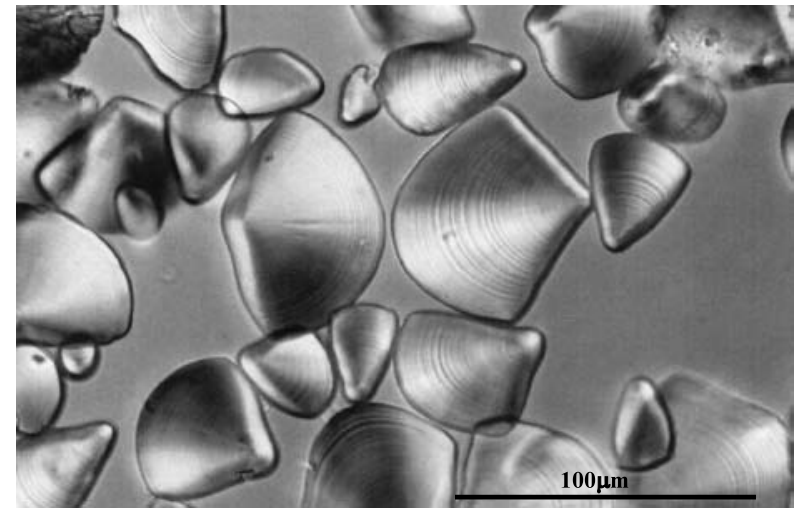

Fig. 4. Optical micrograph of enset starch.

Clamshell-shaped starch granules showed clear growth rings under differential interference contrast microscopy.

white parts between the walls. Figure 2 (B) shows a sketch of a vertical view cut at the dotted line of Fig. 2 (A). The white parts are membrane-like tissues that exist at almost regular intervals between the walls. Figure 2 (C) is a SEM image showing a wall and membranes on both sides. The membrane has a beautiful net structure. In the wall, we observed many soft cells filled with starch granules and also vascular bundle systems. Figure 2 (D) shows starch-accumulating cells of the wall with high magnification observed by SEM. These micrographs indicate that the walls of leaf sheaths, which are used to prepare traditional Ethiopian bread-like food after scraping and fermentation, are starch storing organs in enset just as in the corm. Figure 3 (A) shows a sketch of a cross section of a corm. Outer layers from the periderm as shown in Fig. 3 (B) have only soft cells but numerous cell embedded starch granules are observed in the central part of the corm as shown in Fig. 3 (C) under SEM. The corm may be the main storage organ of enset starch but the shape and size of starch granules in the corm and leaf sheath are morphologically similar.

Clamshell-shaped starch granules with clear growth rings were observed by light microscopy as shown in Fig. 4.

\section{Physico-chemical properties of enset starch.}

Various physico-chemical properties of enset starch were examined as described in MATERIALS AND METHODS. Proximate compositions analysis of the enset starch showed $14.3 \%(\mathrm{w} / \mathrm{w})$ moisture, $0.2 \%(\mathrm{w} / \mathrm{w})$ protein, $0.1 \%(\mathrm{w} / \mathrm{w})$ fat and $0.2 \%(\mathrm{w} / \mathrm{w})$ ash.

\section{Granule size distribution.}

The volume fraction of starch granule size distributions for enset, potato, sago and corn are shown in Fig. 5. The average granule size of enset starch was $37.7 \mu \mathrm{m}$, which was comparable to that of potato starch $(38.2 \mu \mathrm{m})$. Size distribution of the granules showed a normal distribution curve between 15 and $60 \mu \mathrm{m}$, sharper than that of potato starch, which was broadly distributed from 5 to $65 \mu \mathrm{m}$.

\section{$X$-ray diffraction pattern.}

The X-ray diffraction pattern was determined in order to analyze the crystal structure of starch granules. As shown in Fig. 6, the X-ray diffraction pattern of enset
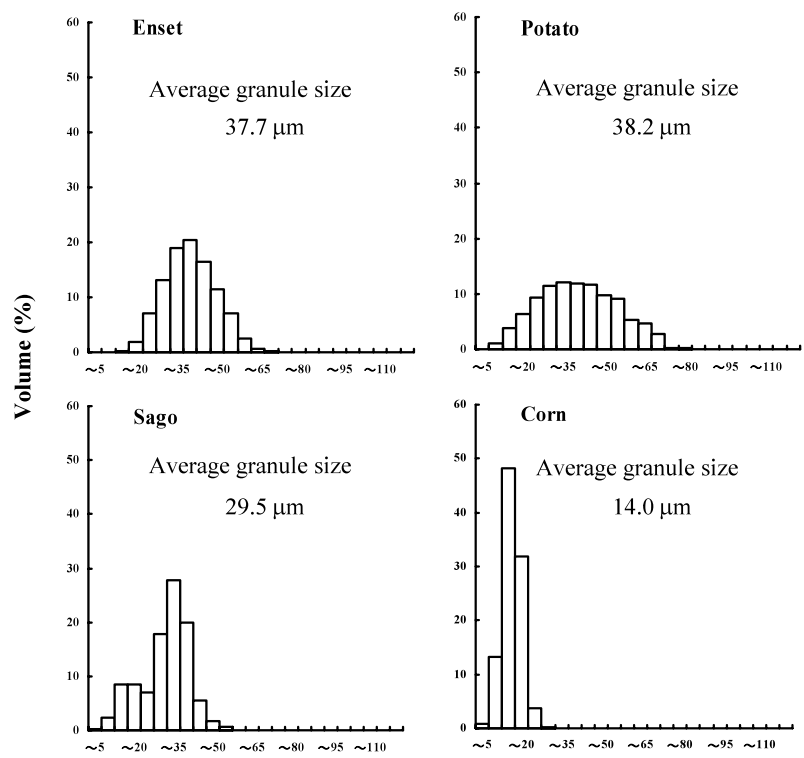

Particle diameter $(\mu \mathrm{m})$

Fig. 5. Granule size distribution of starches of enset, potato, sago and corn.

After dispersing in water, 30,000 starch granules were counted. The average granule size of enset starch $(37.7 \mu \mathrm{m})$ was closer to potato starch $(38.2 \mu \mathrm{m})$. A histogram of enset starch granule size distribution shows a relatively narrow range between 15 to $60 \mu \mathrm{m}$.

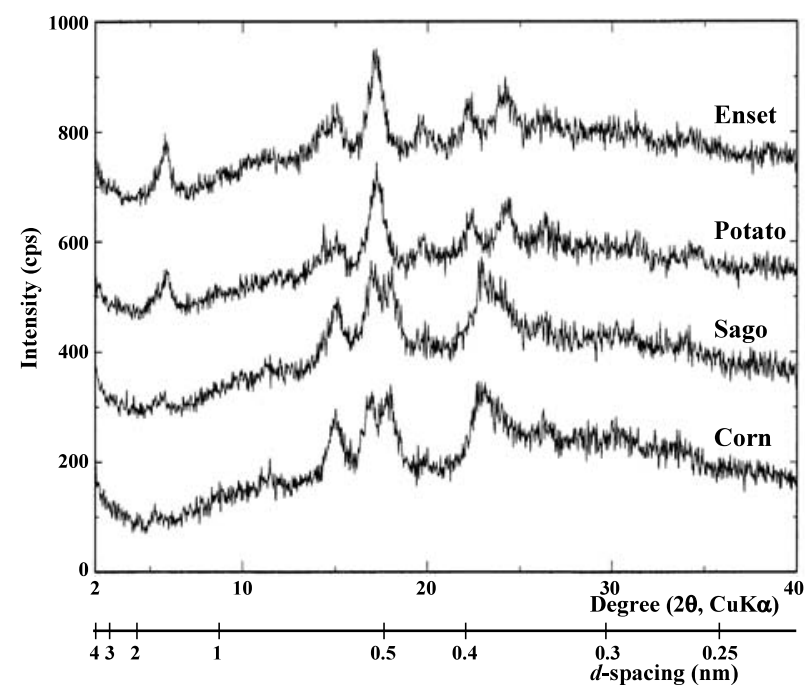

Fig. 6. X-ray diffractograms of starches of enset, potato, sago and corn.

X-ray diffractograms show a B-pattern for enset and potato starches, a C-pattern for sago starch and an A-pattern for corn starch.

starch was a typical B-type as with potato starch; both have sharp No. 1 (1.6 nm reflection) and No. 4 (0.52 nm reflection) peaks in diffractograms. Corn starch showed A-type and sago starch was C-type with a small peak at $1.6 \mathrm{~nm}$ reflection.

\section{Amylose content and whiteness.}

The amylose content of enset starch was $21 \%$ which was close to the $20 \%$ of potato starch. The amylose content of both sago and corn starches was $24.5 \%$ which was higher than that of enset starch. The whiteness of enset starch as a powder was 85.9, which was lower than for corn (100) and potato (95.3) and higher than for sago 


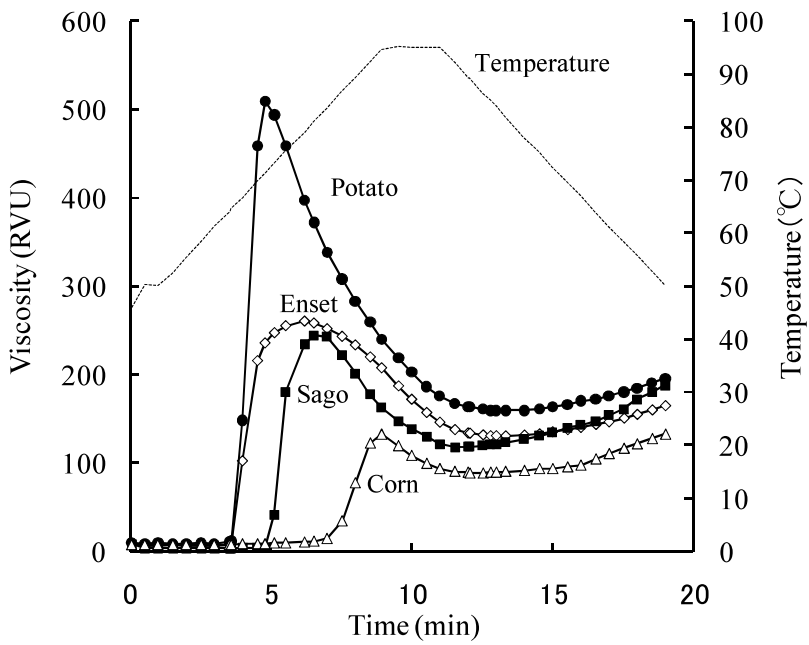

Fig. 7. Viscograms of starches of enset, potato, sago and corn.

Curves of potato, enset, sago and corn indicate the viscosity change (RVU, Rapid Visco Analyzer Unit) of starch suspension during measurement. Temperature (dotted line) indicates programmed temperature change. After being kept $1 \mathrm{~min}$ at $50^{\circ} \mathrm{C}$, the temperature was elevated at the rate of $5.6^{\circ} \mathrm{C} / \mathrm{min}$ until $95^{\circ} \mathrm{C}$. After being maintained at $95^{\circ} \mathrm{C}$ for $2 \mathrm{~min}$, the temperature was dropped at the rate of $5.6^{\circ} \mathrm{C} / \mathrm{min}$ until $50^{\circ} \mathrm{C}$ was reached.

Table 1. Characteristic viscogram values.

\begin{tabular}{|c|c|c|c|c|}
\hline Sample & $\begin{array}{c}\text { Gelatinization } \\
\text { temperature } \\
\left({ }^{\circ} \mathrm{C}\right)\end{array}$ & $\begin{array}{c}\text { Maximum } \\
\text { viscosity and } \\
\text { its temperature } \\
\left(\mathrm{RVU} /{ }^{\circ} \mathrm{C}\right)\end{array}$ & $\begin{array}{c}\text { Minimum } \\
\text { viscosity and } \\
\text { its temperature } \\
\left(\mathrm{RVU} /{ }^{\circ} \mathrm{C}\right)\end{array}$ & $\begin{array}{l}\text { Viscosity } \\
\text { cooled } \\
\text { at } 50^{\circ} \mathrm{C} \\
(\mathrm{RVU})\end{array}$ \\
\hline Enset & 64.6 & $260 / 79.4$ & $130 / 82.0$ & 164 \\
\hline Potato & 63.2 & $680 / 69.3$ & $148 / 89.8$ & 217 \\
\hline Sago & 72.3 & $225 / 82.6$ & $107 / 89.4$ & 171 \\
\hline Corn & 73.1 & $113 / 94.2$ & $76 / 89$ & 129 \\
\hline
\end{tabular}

(80.1).

\section{Gelatinization behavior.}

Gelatinization behavior was examined by determining viscosity change and light transmittance change of starch suspension during continuous heating. A RVA viscogram is shown in Fig. 7 and characteristic figures obtained from viscograms of each starch are indicated in Table 1 . The RVA viscograms of triplicate determination were highly reproducible and almost identical. The gelatinization temperature of the enset starch was $64.6^{\circ} \mathrm{C}$, which was slightly higher than the $63.2^{\circ} \mathrm{C}$ of potato starch. Though the enset maximum viscosity of 260 Rapid Visco Analyzer Unit (RVU) was close to the 225 RVU of sago starch, the rate of viscosity decrease during maintaining at $95^{\circ} \mathrm{C}$ was slower than for sago starch, which suggested the swollen enset starch granules were more resistant to the mechanical shearing of the viscograph.

A photopastegram of each starch is shown in Fig. 8. By using this methodology, a change in starch granules during heating was clearly detected at the initial stage of gelatinization when birefringence of the granules began to be lost under microscopic observation. ${ }^{11)}$ The gelatinization temperature observed by photopastegraphy is always several degrees lower than that determined by viscometry. During the first stage of the gelatinization process, starch

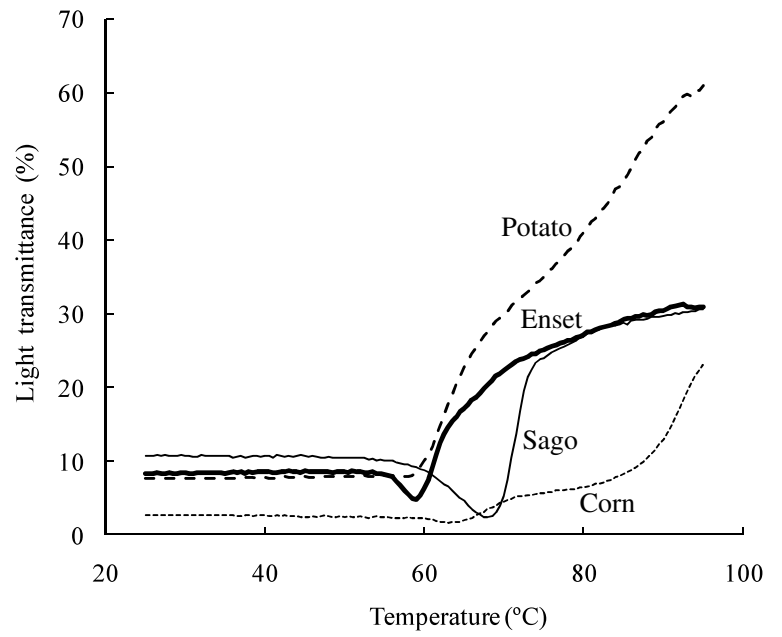

Fig. 8. Photopastegrams of starches of enset, potato, sago and corn.

Light transmittance change of starch suspensions $(0.3 \%, \mathrm{w} / \mathrm{w})$ were determined at $372 \mathrm{~nm}$ while elevating the temperature at a rate of $2^{\circ} \mathrm{C} / \mathrm{min}$.

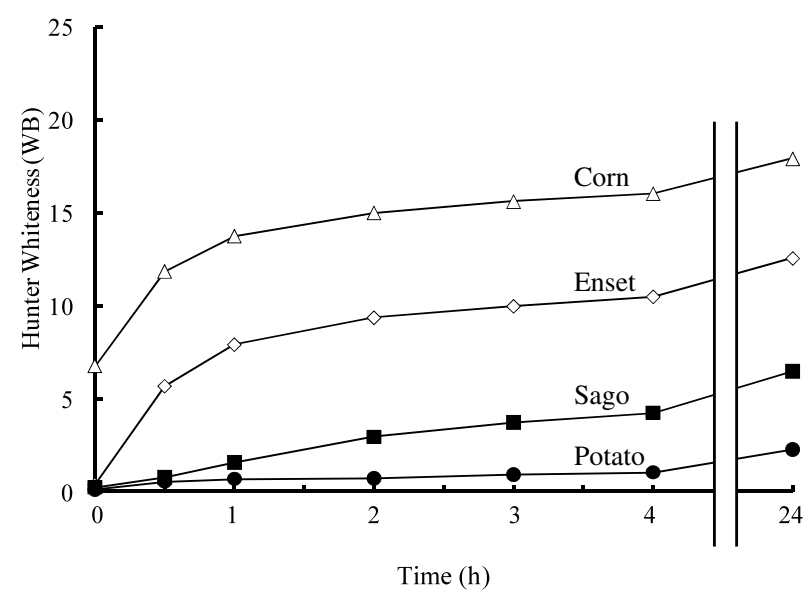

Fig. 9. Change in gel whiteness of starches of enset, potato, sago and corn during storage at room temperature.

granules lost birefringence and became slightly swollen. At this stage, the slightly swollen granules blocked the light path, which caused the decrease of transmittance in the photopastegram of some starches. Following this initial stage, granules rapidly increased in volume by absorbing a large amount of water, which was reflected in the increase of transparency of the starch suspension. Starches were classified into three groups by photopastegraphy. Potato starch increased transmittance directly after gelatinization. On the other hand, corn starch showed two-step gelatinization curves. Sago and enset starch belonged to the third group, where transmittance sharply decreased at the early stage of the gelatinization, then increased. Photopastegraphy is an extremely sensitive tool to observe the minute change that occurs in starch granules at the initial stage of the gelatinization phenomena. ${ }^{11)}$

\section{Change of whiteness of starch gels during storage.}

Changes in Hunter whiteness of starch gels during storage were determined. These curves reflected the tendency of the retrogradation of starch gels as seen in Fig. 9, where the average values of Hunter whiteness of ten determinations were plotted. The whiteness was highly re- 

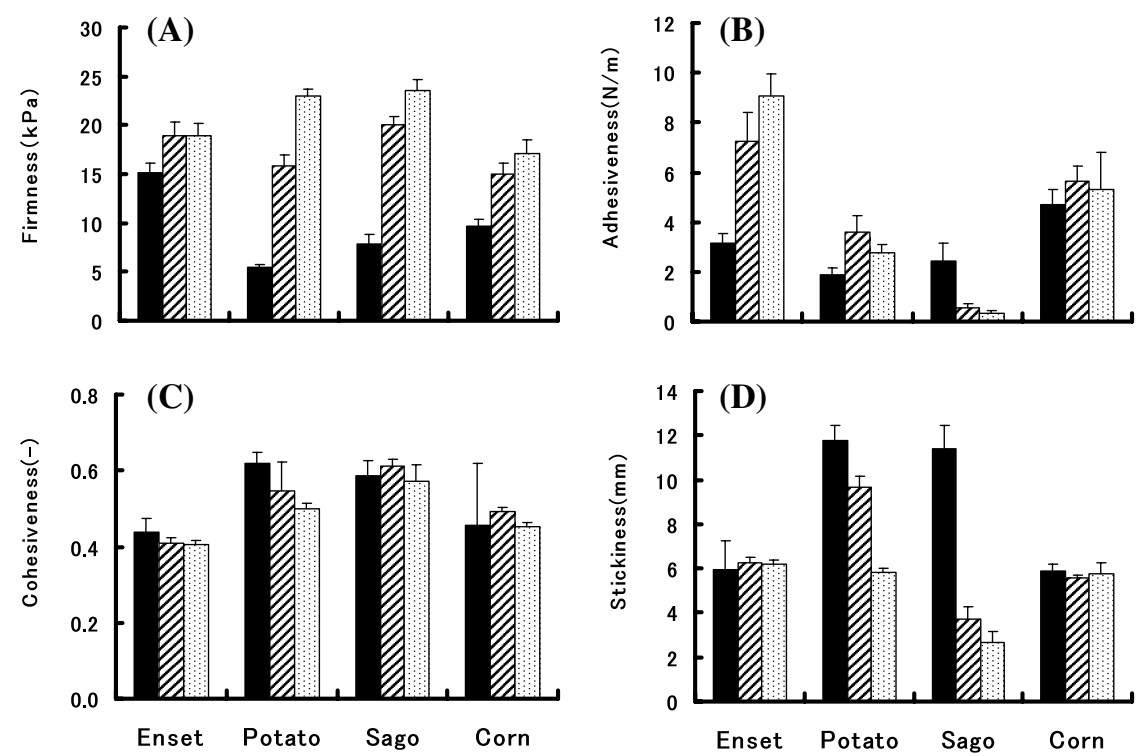

Fig. 10. Characteristic properties of gels of starches of enset, potato, sago and corn.

Firmness, adhesiveness, cohesiveness and stickiness of starch gels were determined after 30 min at $25^{\circ} \mathrm{C}$, then kept at $5^{\circ} \mathrm{C}$ for $2 \mathrm{~h}$ and $24 \mathrm{~h}$. Bars in graphs are indicated as follows: , after $30 \mathrm{~min}$ at $25^{\circ} \mathrm{C}$; VIIIA, after $2 \mathrm{~h}$ at $5^{\circ} \mathrm{C}$;.

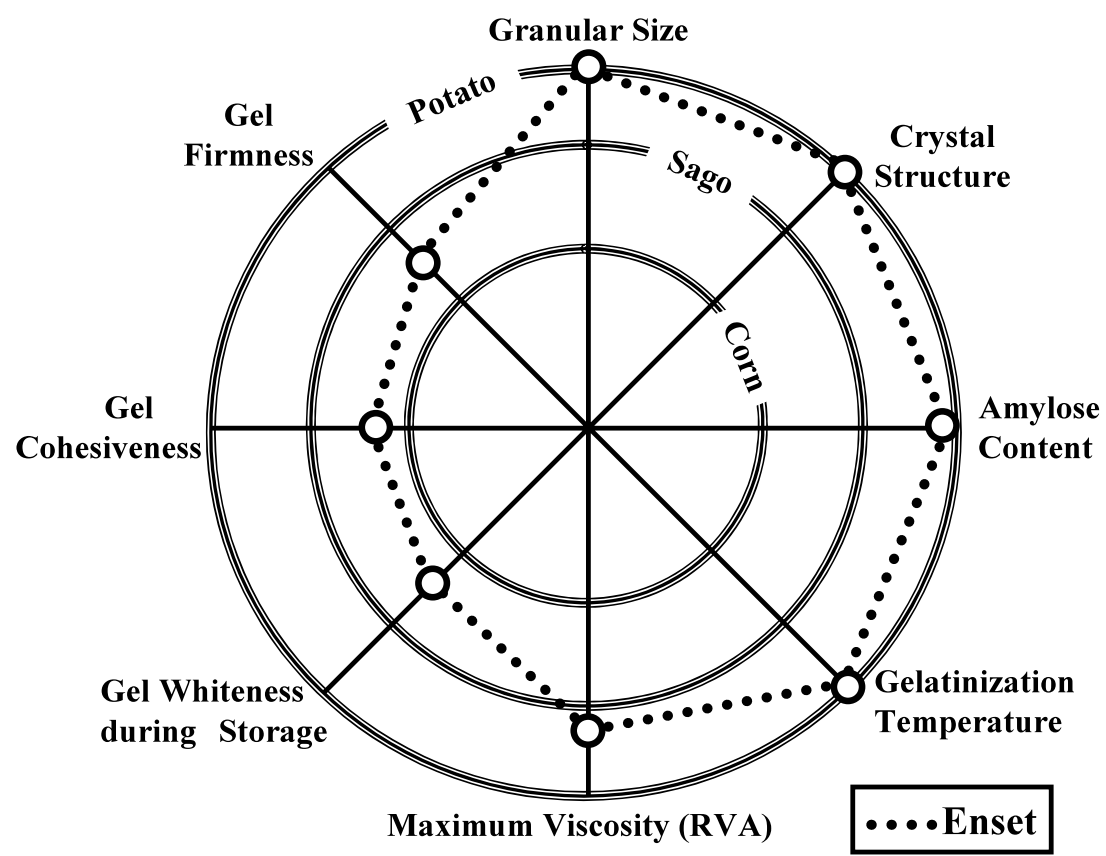

Fig. 11. Starch diagram of enset starch.

Characteristic properties of enset starch are compared with those of potato, sago and corn starch. The cross points of circles representing potato, sago, corn and the linear line of selected properties represent the determined value of each starch. Small circles $(\bigcirc)$ linked by the dotted line show the similarity of enset starch with reference starches.

producible and standard deviations of ten determinations were within the range of 0.02 to 0.5 for the starches examined.

Immediately after the preparation of gels, enset starch showed low whiteness comparable to starches of potato and sago. The whiteness of enset began to increase after $15 \mathrm{~min}$ at room temperature. During storage the whiteness of enset starch increased rapidly, becoming substantially whiter than sago and potato starches but not as white as corn starch. As mentioned above regarding the change of transmittance during gelatinization determined by photopastegraphy, the curve of enset starch resembles that of sago starch. However, the behaviors during the storage of starch gels were closer to that of corn starch. These phe- nomena suggest that useful properties of enset starch are closer to potato and sago starches in granule form or gelatinization process, but after gelatinization, enset starch gel behaves more like that of corn starch.

\section{Characteristic properties of enset starch gel.}

Physical properties such as firmness, stickiness, adhesiveness and cohesiveness of enset, potato, sago and corn starch gels determined by uniaxial compression rheometer are shown in Fig. 10. Though the initial firmness $(14.7 \mathrm{kPa})$ of enset starch gel determined after standing for $30 \mathrm{~min}$ at $25^{\circ} \mathrm{C}$ was twice those of starch gels of potato and sago, the firmness only slightly increased during storage at $5^{\circ} \mathrm{C}$ for 2 and $24 \mathrm{~h}$ while the other reference 
starch gels increased in firmness substantially and became firmer than that of enset (Fig. 10 (A)). The adhesiveness of enset starch gel was the highest among the starch gels examined and increased further during storage (Fig. 10 (B)). Cohesiveness, internal gel strength caused by gel cohesion, was the lowest among the compared gels of potato, sago and corn (Fig. 10 (C)). The stickiness of enset starch gel was stable during storage at $5^{\circ} \mathrm{C}$, which was close to corn starch gel (Fig. 10 (D)). Potato and sago starch gels showed higher stickiness at the initial stage but drastically decreased during storage at $5^{\circ} \mathrm{C}$. From these results, we observed that enset starch gels increased adhesiveness, but did not change firmness, stickiness or cohesiveness during low temperature storage at $5^{\circ} \mathrm{C}$.

\section{DISCUSSION}

We have determined the characteristic properties of enset starch from various physico-chemical points of view. Granule size, X-ray diffraction pattern, amylose content, gelatinization temperature, maximum viscosity, gel whiteness, gel cohesiveness and gel firmness were selected as important characteristic properties and are shown in Fig. 11 as a starch diagram. The starch diagram was developed by one of the authors, Kainuma, for use in demonstrating the characteristic properties of sago starch in comparison with other well utilized starches. ${ }^{13)}$ The advantage of the diagram is that it simply expresses the similarity of a novel starch with well characterized starches ranging over a whole gamut of starch properties in one diagram. Therefore, it is an excellent demonstration tool for showing useful properties of an unknown starch by the comparison with well known starches. The cross point of circles of potato, sago, corn with the linear line of a selected property represents the determined value of each starch. Measured values of enset starch are plotted as a circle in the figure in order to compare with those of reference starches. The dotted line obtained by linking circles indicates relative similarity of enset starch with reference starches.

The granule size, amylose content, X-ray diffraction pattern and gelatinization temperature of enset starch have a high degree of similarity with potato starch. The maximum viscosity of enset starch is much closer to that of sago starch. The gelatinization process of enset starch started at the same temperature as potato starch and the maximum viscosity of the paste was closer to that of sago starch. However, the viscosity curve of enset starch was different from those of reference starches as shown in Fig. 7.

After the starch was gelatinized and became a gel, the behaviors of enset starch were more similar to those of corn starch. The changes in gel whiteness during storage lay between those of sago and corn. This indicated that enset starch retrograded faster than sago and slightly slower than corn. Rheological properties represented by cohesiveness, adhesiveness and firmness of enset starch gel were comparable with those of corn starch. The enset starch paste quickly formed a fragile gel during storage, which was similar to the behavior observed of corn starch.
Enset starch has been evaluated as a binder and disintegrant for compressed tablets, due to the better binding stability and lower disintegrating power than potato starch. Based on the observations of this study, we would like to add the useful characteristic properties of enset starch for foods. The characteristics of gelatinization behaviors, quick gel formation, gel stability during cold storage, stable firmness and stickiness of enset starch gel demonstrated in this paper would be useful for various food uses, for example in Blanc-mange and the Japanese sweet Kudzu mochi as body formation, and in various soups and sauces including Tare-mop sauce- as thickener due to its stable viscosity and stable strong gel stickiness during storage. The gel whiteness of enset starch is appropriate for milk or soybean curd containing processed foods in which pure white color is appreciated. Properties of enset starch gel will be useful as a body forming agent of various foods in home cooking and food industries.

The authors thank Mr. Yitbarek Alemu, General Manager of Starch Chemicals \& Adhesive Industry and Mr. Toshiro Mado of Sasakawa Africa Association (SG2000) for providing enset starch. The authors also thank Drs. Michael Cohen and Mami Kainuma for their critical reading and editing of the manuscript.

\section{REFERENCES}

$1)$ K. Zippel: Enset (Ensete ventricosum (Welw.) Cheesm.) in Subsistence Farming System in Ethiopia. http://www. tropentag.de/2002/proceedings/node60.html (2002).

2 ) American Association for the Advancement of Science: The Tree Against Hunger: Enset Based Agricultural System in Ethiopia. http://www.aaas.org./international/africa/enset/ descrip.shtml (1998).

3 ) T. Gebre-Mariam and P.C. Schmidt: Isolation and physicochemical properties of enset starch. Starch/Stärke, 48, 208214 (1996).

4 ) T. Nakazato and T. Watanabe: Analysis of moisture. in Nihon Shokuhin Hyojun Seibunhyo Bunseki Manual, K. Yasumoto, M. Takeuchi, A. Yasui and T. Watanabe, eds., 5th Ed., Kenpakusha, Tokyo, pp. 9-21 (2006).

5 ) N. Yoshii: Analysis of protein. in Nihon Shokuhin Hyojun Seibunhyo Bunseki Manual, K. Yasumoto, M. Takeuchi, A. Yasui and T. Watanabe, eds., 5th Ed., Kenpakusha, Tokyo, pp. 22-27 (2006).

6 ) Y. Sakano: Determination of fat in starch. in Denpun Kanrentoshitsu Jikkenho, M. Nakamura and K. Kainuma, eds., Gakkai Shuppan Center, Tokyo, pp. 34-35 (1986).

7 ) N. Yoshii: Analysis of ash. in Nihon Shokuhin Hyojun Seibunhyo Bunseki Manual, K. Yasumoto, M. Takeuchi, A. Yasui and T. Watanabe, eds., 5th Ed., Kenpakusha, Tokyo, p. 54-56 (2006).

8 ) L.B. Deffenbaugh and C.E. Walker: Comparison of pasting properties in the brabender viscoamylograph and the rapid visco-analyzer. Cereal Chem., 66, 493-499 (1989).

9 ) T. Baba: Quantitative analysis of amylose and amylopectin in starch. in Denpun Kanrentoshitsu Jikkenho, M. Nakamura and K. Kainuma, eds., Gakkai Shuppan Center, Tokyo, pp. 89-93 (1986).

10) K. Kainuma, T. Oda and S. Suzuki: Determination of gelatinization of starch granule by photopastegraphy (Part 1). Design and trial manufacture of photopastegraph. Denpun Kogyo Gakkaishi (J. Technol. Soc. Starch), 16, 51-54 (1968).

11) K. Kainuma, T. Oda and S. Suzuki: Determination of gelatinization of starch granule by photopastegraphy (Part 2). Analysis of gelatinization temperature of various starch granules by photopastegraphy. Denpun Kogyo Gakkaishi (J. Technol. Soc. Starch), 16, 54-60 (1968). 
12) A. S. Szczeniak: Classification of textural characteristics. $J$. Food Sci., 28, 385-389 (1963).

13) K. Kainuma: Present status of starch utilisation in Japan. in Sago-76, Papers of the First International Sago Symposium "The Equatorial Swamp as Anatural Resource" (1st 1976, Kuching), K. Tan, ed., Kemajuan Kanji Sdn. Bhd., Kuala Lumpur, pp. 224-229 (1977).

\section{エンセット (Ensete ventricosum) 澱粉の特徵的な 物理化学的性質と潜在的な利用特性 \\ 一馬鈴薯, サゴ, トウモロコシ澱粉との比較研究—} 廣瀬理恵子 ${ }^{1}$, 手塚尚子 ${ }^{2}$, 近堂知子 ${ }^{2}$, 平尾和子 ${ }^{3}$

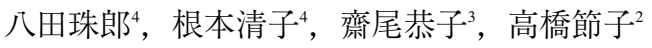
貝沼圭二 ${ }^{4}$

'東京都立食品技術センター (101-0025 東京都千代田区神田佐久間町 1-9) 2 共立女子大学家政学部

(101-8437 東京都千代田区一ツ橋 2-2-1) 3 愛国学園短期大学

(133-8585 東京都江戸川区西小岩 5-7-1) 4 国際農林水産業研究センター (305-8686 つくば市大わし 1-1)

エンセット (Ensete ventricosum) はバショウ科に属し, エチオピア南部および南西部においてのみ栽培されてい る植物である，植物の形状はバナナに似ているが，果実 をつけず葉鞘および球茥 (corm) に澱粉を蓄える。この澱 粉は発酵させてパン状の食品 (Cocho) として食されるほ か, 抽出された澱粉は広く食品として利用されたり，纎 維や紙のサイジング (糊つけ) 剂として用いられている. しかし，エンセット澱粉の物理化学的性質を調べた報告 は非常に数少ない. 本報では，広く用いられている馬鈴 薯澱粉，トウモロコシ澱粉，エンセットと同様に幹に蓄 積されるサゴ澱粉と比較する目的で, アミロース含量, 粒度分布, 糊化の際の挙動をラピッドビスコアノライ ザーおよびフォトペーストグラフィーを用いて測定した. また，得られたゲルについては保存中の白度の変化，ゲ ルの力学物性を測定した。これらの結果を Starch Diagram (Fig. 11) に表示した. X 線回折図型, 平均粒径, アミ ロース含量, 加熱の際の糊化開始温度などは馬鈴薯澱粉 に近いが，糊化した後の糊の最高粘度，冷却時のブレー クダゥンはサゴ澱粉に近い. ゲルの凝集性, 粘りなどの 数值はトウモロコシ澱粉に近く, 一部トウモロコシ澱粉 とサゴ澱粉の中間に位置した。以上のような糊化特性, 迅速なゲル形成性, 低温でのゲルの安定性, 硬いゲル強 度などは, ボディ形成剤としてブラマンジェ，葛餅など に適し，付着性は種々のソース，スープの増粘用に適し ている. 以上のような特徵をもつエンセット澱粉は家庭 用の調理澱粉，また食品産業において用途が広いものと 考えられる。 